\title{
Changes in management actions after the Hospital Accreditation
}

\author{
Mudanças nas ações gerenciais após a Acreditação Hospitalar
}

\author{
Andréia Guerra Siman ${ }^{1}$, Simone Graziele Silva Cunha², Maria José Menezes Brito ${ }^{2}$
}

Objective: to understand the changes in the management actions after the Hospital Accreditation. Methods: a case study. The study included 12 managers of a hospital accredited with excellence. Data collection was carried out with interviews with semi-structured and subjected to content analysis. Results: about changes in management actions were recorded significantly three categories: Work organization with quality tools; management actions before and after the accreditation; and challenges faced by modifying the management actions. Conclusion: accreditation mobilized changes in management actions with quality instruments of adoption used to organize the work and accountability of those involved in the process. However, there were challenges to be overcome to achieve accreditation by managers.

Descriptors: Accreditation; Quality Management; Management; Hospitals.

Objetivo: compreender as mudanças nas ações gerenciais após a Acreditação Hospitalar. Métodos: estudo de caso. Participaram do estudo 12 gerentes de um hospital acreditado com Excelência. Coleta de dados realizada com entrevistas, roteiro semiestruturado e submetidos à análise de conteúdo. Resultados: em relação às mudanças nas ações gerenciais foram constituídas de forma significativa três categorias: Organização do trabalho com ferramentas da qualidade; Ações gerenciais antes e após a acreditação; e Desafios enfrentados ao modificar as ações gerenciais. Conclusão: a acreditação mobilizou mudanças nas ações gerenciais com adoção de instrumentos da qualidade utilizados para organizar o trabalho e a responsabilização das pessoas envolvidas no processo. Entretanto, surgiram desafios a serem superados pelos gerentes para alcançar a acreditação.

Descritores: Acreditação; Gestão da Qualidade; Gerência; Hospitais.

${ }^{1}$ Universidade Federal de Viçosa. Viçosa, MG, Brazil.

${ }^{2}$ Universidade Federal de Minas Gerais. Belo Horizonte, MG, Brazil.

Corresponding author: Andréia Guerra Siman

Av. Peter Henry Rolfs, s/n - Campus Universitário, CEP: 36570-900. Viçosa, MG, Brazil. E-mail: ago.80@hotmail.com 


\section{Introduction}

Organizational managers of health have made efforts to seek improvements in quality, patient safety and, therefore, they are often developing strategies to achieve Hospital Accreditation.

In Brazil, accreditation is characterized as a voluntary, periodic and reserved process, which tends to ensure the quality of care through previously accepted standards ${ }^{(1)}$. When it is implemented effectively, accreditation is a chance to evaluate and promote quality improvement in hospitals, since it causes changes in habits, values, welfare and management behaviors as contributing to a more skilled care, and foster an organizational excellence environment ${ }^{(2)}$.

The initiative of the national accreditation process is strengthened especially with the methodology Joint Commission on Accreditation of Health Care Organization and the National Accreditation Organization.

The International Joint Commission was established in 1998; a division of the Joint Commission and its mission is to improve health services in the international community through accreditation and to consult. It is a methodology for assessing and improving the quality of health ${ }^{(3)}$. The Brazilian Accreditation Consortium was created to contribute to the improvement of the quality of hospitals and other health services. It is the organization responsible for applying the methodology in Brazil ${ }^{(3)}$.

This study focuses on the evaluation of quality by the methodology of the National Accreditation Organization, an entity created in 1999 and responsible for accreditation in the country that aims to promote an ongoing process of substantiated education in the value that is given to a reality in the face of a reference or pattern, followed by a systematic evaluation ${ }^{(1)}$. Also, it is scoped to deploy assess and certify health institutions based on an evaluation of safety, structure, process and results according to the highest quality standards ${ }^{(1)}$.
Thus, quality management has contributed to the development and satisfaction of professionals and managers, increasing the efficiency and effectiveness of financial, organizational processes and customer requirements of service ${ }^{(2-4)}$.

In this sense, the evaluation of health services involves management actions that consider the triad assessment quality of health care: structure, processes and results ${ }^{(5)}$. The structure is the physical, human, material and financial resources for health care; the process corresponds to activities involving health professionals and patients, including diagnosis, treatment, ethical aspects of professional relationship; and the result refers to the final product of care, including health, usage patterns and user expectations $^{(5)}$.

Thus, accreditation is a key management strategy in seeking assistance with more quality and safety, with results management. As a result, it is chosen to search reference in quality and patient safety in a hospital accredited with excellence.

In this perspective, it is assumed that the scope of accreditation requires efforts of managers, improving service management combining security with professional ethics, responsibility and quality of care $^{(6)}$, and, therefore, generates management changes as the development of knowledge, skills, and abilities. Given the above, there is the central question of this study: what are the changes in management actions after the Hospital Accreditation?

The aim of this study was to understand the changes in management actions after the Hospital Accreditation to contribute to health management in the hospital setting.

\section{Methods}

This is a case study. The case study will largely meet the changes in management actions that occurred after the implementation of accreditation, as this method tells the holistic and meaningful characteristics of a phenomenon ${ }^{(7)}$. The qualitative 
research attempts to capture the dynamic and individual aspects of each phenomenon, exhibiting everything that surrounds the object ${ }^{(8)}$. Thus, the changes that occurred in the management actions will be understood.

One Excellence accredited hospital was chosen to address the research question of this study and achieve the proposed objective, level three in the national methodology since 2004. Also, the choice of this scenario was because it is one of the first hospitals in Belo Horizonte to get this certification. It is a private, large hospital, located in Belo Horizonte, Minas Gerais, Brazil.

The research subjects were the professionals working in management positions after certification and participated in the implementation of hospital accreditation since the beginning of the process, being the inclusion criteria. Thus, managers who did not experience the beginning of certification at the institution were excluded. Thus, the total number of participants in the research including the ascribed criteria were 12 subjects (five nurses, two doctors, an accountant and four directors). It is noteworthy that the sample was closed by the criterion of saturation information, and therefore, there were no losses. Saturation occurs as the collected data becomes repetitive and redundant, thus, it does not proceed with the interviews because it does not generate more new knowledge ${ }^{(8)}$.

Data collection was conducted through interviews with a semi-structured script, from April to June 2011 and recorded before subjects authorization and transcribed in full. The questions assessed aspects such as management activities, management actions before and after the accreditation process and the role of professionals in this process, and facilitating and hindering aspects. It is noteworthy that the interviews were conducted in the workplace of the subjects, previously scheduled.
The collected data were submitted to content analysis, which allows uncover and understand the relationships that are contained in the messages, seeking to achieve a deeper interpretation of the phenomenon and a merely descriptive scope of the manifest content of the message. Data analysis was carried out on three chronological divisions: preanalysis, exploration of the material and processing of the results ${ }^{(9)}$. The pre-analysis phase of organization aims to operationalize and systematize initial ideas to lead to a precise scheme of development of the research. This is where the initial reading, the corpus constitution and reformulation of hypotheses and objectives are performed, forming categories. The exploitation of the material is the operation analyzing the text systematically according to the formed categories. Data processing are inferences and interpretations ${ }^{(9)}$.

The study complied with the formal requirements contained in the national and international standards of regulatory research involving human beings.

\section{Results}

A heterogeneous group of professionals in different categories was identified with a predominance of health professionals (75.0\%). The participants in the study were 12 managers: five nurses, four doctors, two directors and an accountant, checking the prevalence of nursing professionals' management positions. They were seven women $(58.3 \%)$ and five men $(41.7 \%)$. The age of managers ranged between 29 and 58 years old, and the average working time in the institution was 13 years. After certification, all remained occupying managerial positions. Regarding the performance of graduation, $100.0 \%$ of the professionals conducted a specialization course. 
Concerning the changes in management actions, the following categories were recorded significantly: Work organization with quality instruments; Management actions before and after accreditation and Challenges faced by modifying the management actions.

\section{Work organization with quality instruments}

Managerial activities are now recorded and documented more organized and systematized with the certification. What has changed is that from the accreditation, I have more instruments in a more standardized way. I know where to look for the information and know what I have. So before, if asked me some information, I had to search if I had this information, or sometimes create it, or sometimes it was informal, and I had to do a report. Today, after accredited, this availability that you know the numbers more easily. You have more information in real time and in a standard way, recorded. You know where to look and why, and what it is for (GR11). Today, we have more tangible tools to better direct their service improvement activities that are commonplace: people management, range management, unit management, mount a drive, material, medicine available. The processes were best described, giving a better quality of care and patient safety (GR3).

Managers began to use quality instruments, which could be called administrative, or quality tools. In this study, it was chosen to call them as quality instruments. Thus, the managers of this study highlighted that started to use instruments such as action plan; indicators; critical analysis of the actions; chain customer-supplier; risk matrix and cause analysis.

Managers pointed out the importance of the work with quality instruments, not identifying these tools just as bureaucratic or overloading the work, but mainly as facilitators of the development of a more organized work, with more tangible data, reflecting the quality of care and in continuous improvement. More organized work is to ensure quality through this quality tool to do and follow it better, through the proximity it offers so that it is closer to management on a daily basis. It is not one more thing to do (GR8).

The instruments used are perceived as tools that came to streamline the care process with commitment and responsibility.

Regarding the action plan, the institution held strategic planning. We already worked with planning, strategic planning; we have had since 1996, which was a facilitator. Because we had internal goals, we had to do an analysis of these goals, why to achieve these goals or not (GR9). Strategic planning is reviewed every six months by scrolling held with senior management with strategic goals for the organization. Each sector has a specific goal, which is the breakdown of hospital strategic goals (GR7). We had the strategic planning procedures, we had critical analysis, but in a more informal way, not now. Now the hospital is already accredited since 2004 (GR8).

The work of managers with a focus on strategic planning takes place informally, being developed in each sector an impromptu work without planning actions. With the accreditation, managers began to perform operational planning; action plans with shortterm plans of the units, the continuous monitoring of the results clarifying the objectives, methods, resources, actions and goals flush with the strategic planning of the hospital. These plans were carried out through formal meetings between various sectors of managers and their employees.

It was found that managers began to use the indicators to monitor the certification of results. Then, it is a set of tools to keep up, measure indicator. This is monthly, and see it as a facilitator. It is necessary to be charged to leave everything within (GR10). Before accreditation, the processes already existed but were not uniform throughout the hospital. For example, the intensive care unit had the care indicators, some administrative, but had sectors that had not (GR3). We realize that once involved with the accreditation process, which involved it began more or less in 2002, and we were certified in 2004, we notice a more systematic. So you have the indicators that you do, you measure. So have a place for it, 
justifies, makes action plan but in a more systematic way. Today, you have instruments that qualify best for you to do this (GR4).

Another instrument adopted by managers was the use of critical analysis. The critical analysis we do in medical clinics, each nurse is responsible for the analysis of both the care point of view and management of the sector, we have acquired over time (GR2). In addition to the accreditation, it brings us security in our management work also brought the necessary documentation. Today, all our documents are recorded in a matrix, all our activities are documented records and periodically reviewed, operational procedures, and we also work with indicators to monitor the performance of our work, in addition to critical periodic reviews and internal and external audits, we maintain our proper way to work (GR6). So, there is a much greater concern with prevention rather than correction. So today, we have more preventive plans than correctives ones. This changes the way you manage, yes, to anticipate the problem. Moreover, it happens to the monthly analysis or fortnightly and analyzes critical of senior management in all sectors have to be present to talk about their planning and analysis of its sector (GR10).

It is interesting to highlight that each manager was responsible for the critical analysis of their area, and these analyzes constantly perform in the short term as monthly or fortnightly. It was necessary to present them to the hospital board and other managers from various sectors in meetings. The critical analyzes were carried out in a systematic way, and all managers have developed, revealing evidence of improvement and innovation performance.

It is also noticed the customer-supplier chain. The statements below make clear the importance of the use of this instrument. We have to be able to meet our internal customer in the customer-supplier chain requirements. This chain is very well-established, structured and clear. So we do not like having a different expectation or with management or with the employee. If it is aligned with the values, the culture of the institution, especially with the strategy, where this institution wants to go and what goals, it is quiet (GR7). We are a reference center for the care of the patient. So, what happened is that we cleared, we started to show some very concepts of internal customer, customer-supplier chain.
This was a growing (GR2). We went to work in a more synchronized way. No one imposes anything; it is discussed and agreed. Each sector amounts to the customer-supplier chain, and we discuss how you want to receive the product and how you want to provide the product. So, it is agreed (GR10).

The adoption of risk matrix after accreditation is evident, which helped manage the risks in the sectors. The most commonly used tool for risk management by managers of this study was the cause analysis, which is an old tool in the administration, but new in health. Therefore, managers express more difficult to develop it: One thing that stands out of this whole issue of management for accreditation is the question of risk management because it is something new, is gain for the institution that now has no way a company survive if you are not managing this risk, mainly a health institution (GR10).

Despite being a new process, which implies difficulties by the manager process, risk management has been incorporated gradually into the daily lives of managers. Moreover, today it is more focused on risk management. So, I think it'll adding and adding value as well. Before, we worried about the processes and the record, and then the indicators, then with continuing education towards continuous improvement. Now, risk management, and so on (GR6).

Risk management with cause analysis is not an option. It is a matter of survival for the health organization because there is the challenge of developing practices for patient safety.

\section{Management actions before and after accredita- tion}

On the management actions, there are variety and complexity actions taken by managers, reflecting the managerial function before and after the implementation of hospital accreditation.

In Figure 1, we observe the changes identified in the management activities that the accreditation process brought to this function, according to a report of the study participants. 


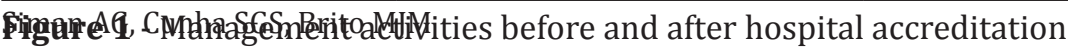

\section{Challenges faced by modifying the management actions}

In this category, it was highlighted the challenges that managers explain in the statements. It was necessary to acquire maturity about the accreditation process, which can only be achieved with time and training. Thus, we already have the maturity about the much larger management process than seven years ago, and this results in an improvement both for managers and for the hospital. Consequently in achieving the goals too (GR8).

The manager tried to develop different skills developed earlier, such as communication and leadership. At the time, one of the main criteria was the same training. However, I think now most is the leadership process (GR3). The manager is motivating. He is directly responsible for the process and the result also. In his hands is motivating the team, prepare, track, train, and then do the review with the management board of the hospital (GR6).

When speaking of quality instruments, respondents cite other challenging aspects. From the perspective of the respondents, they needed to acquire knowledge and skills to work with these instruments of effectively quality. Considering most managers operating in the hospital are Master's degree in health, these challenges become even greater. Thus, I am producing, I have to give assistance, have to cash in on what I proposed. I have several employees, several indicators that will show management if everything is what he proposed to manage people, which is good financially, strategically market. This because I have ten years of service. For me, it was a very big gain, because in our profession we do not learn it in school, and the accreditations we had to learn a lot and so the area became more organized. Professionally I also gained a lot because I graduated in 1985 I mean, if I were not in this business I would be today only in doing, and now I can associate to do with numbers, with results that are tangible, I can see where I have to work on my team (GR5).

From the interviewees, managers have gone through a challenging experience, a period of organizational changes and management actions. They lacked a performance efficiently and effectively after insertion of quality tools. Moreover, in my work, what changed most was the management, because we became very attached to the assistance and we got completely lost within this framework of analysis, administrative instruments. Regarding the indicator, if, is this influencing? If is it is going to change? My vision has changed. The hospital has grown not only structurally, but intellectually. Things were easier to see and work with results (GR3).

The managers expressed on management that has become more complex, requiring more knowledge, more production, and better development. I saw how much I grew up here. They give you opportunities. You have to know to take advantages of this opportunity and put it forward. Thus, I added knowledge, professional, personal growth; any company out there catches you at the time. There are courses, I go to São Paulo, companies that make progress here, and open spaces for us, and pay courses for us, we earn much, much knowledge. At first, as we had no experience, everyone was like, "we has to do, have to do" much pressure, for God's sake! What happened? The National Accreditation Organization arrived, it took very structure, process, result, NAIHO came (International Organization for Standardization), following the patient, patient care, that is, we turn a wonder woman (GR5).

The reports presented in this category can be inferred that one of the greatest difficulties of managers was to use the instruments that involved evaluation of the results. However, it provided feelings of achievement and professional opportunity.

\section{Discussion}


The hospital accreditation process, from the perspective of the respondents, contributed to a managerial role with more security and autonomy in decision-making, developing communication skills, leadership, and knowledge. Therefore, there was the development of technical, personal and professional skills, with a more effective management, describing the service and meeting the organization's expectations. There are skills to use knowledge, experience, methods, techniques and equipment to achieve goals and objectives. The leadership also appears in the results as a human skill that is characterized by the ability to work with people in teams, interacting, listening, motivating and coordinating ${ }^{(10)}$.

It is noteworthy that as the philosophy of quality was inserted into the organization; more work required skills and professional training. Thus, organizational change established different postures of managers.

The results presented showed that the resources or means available for management action were guided by the Manual of Health Service Provider Organizations; the Brazilian Manual of Accreditation; to reach the proposed goals ${ }^{(1)}$.

Strategic planning is the administrative tool that has most contributed to the effectiveness of the organization, created to establish policies to achieve the objectives in the 1960s and has a strong interaction with the tactical and operational planning of the sectors, assertive corroborating the present study ${ }^{(11)}$. The principle of strategic planning is to present the sectoral planning of interconnected and interactive manner, that is, strategic planning alone is insufficient $^{(11)}$.

In addition to planning, managers established indicators to measure systematically work process. The use of indicators allows concentrate and learn more quickly about safety and quality care. As a rule, the indicators should cover a broad base with various safety and quality levels ${ }^{(12)}$. The Joint Commission on Accreditation of Health Care Organization elaborated indicators, standards and criteria for the improvement of care and trinomial evaluation, education, and consultancy, which has to be emphasized in an attempt to ensure the quality of health services ${ }^{(13)}$.

For national certification, these indicators need to be aligned and correlated with the organization's strategies. Moreover, it is a prerequisite for the institution to be accredited in Excellence, meet the monitoring and control of program results through predefined goals ${ }^{(1)}$, issues raised in this study.

The adoption and maintenance of indicators are relevant since it allows monitoring and identifying points of improvement of all sectors to achieve quality. Its analysis guides the management decision on the priority actions $^{(14)}$.

Another instrument pointed out the results of this study focuses on the critical analysis of the actions, which is in management actions to establish a cause and effect relationship between the indicators, where the outcome of one influences the other and allows critical analysis of the performance and decisionmaking. Thus, the manager identifies opportunities for improvement and innovations resulting from this ongoing review process, ensuring commitment to excellence $^{(1)}$.

There is also the customer-supplier chain. The manager identifies his suppliers and customers and draws his systemic interaction; that is, formalizing the interaction processes between customer and suppliers, evaluating his effectiveness and promoting improvement actions and learning ${ }^{(1)}$. It is a treaty agreement between the parties, customer, and supplier to improve results, fulfill the duty as the deadline more efficiently and effectively. The customer-supplier chain is a simple and easy tool to apply. It assists the realization of the actions correctly the first time and help in the relationship with stakeholders, developing greater interaction. 
However, even with specific tools to improve the quality of care, all professionals must be committed to the philosophy of quality, able to use these tools and especially be true connoisseurs of the entire organizational process. It is also important to stress the need for expectations reconciled between the top management and the employees, which reinforces the need to maintain a flow of communication and efficient information.

In this same line of thinking, risk management involves cycles of prevention, detection and mitigation of risk, to ensure a safe system ${ }^{(1)}$. Risk management translates as combined transdisciplinary efforts to achieve objectives such as lower risks, culminating in a possible adverse event, regarded as any damage or injury caused to the patient by the intervention of the health team causing inestimable damage ${ }^{(15)}$. Thus, risk management aims to promote safety in the actions, improving patient care and job security ${ }^{(15)}$. Question to manage risks was found in the results of this study, therefore, must be met from level 1 certification by the National Accreditation Organization. These levels follow defined standards in increasingly complex and specific principles: Level 1 (Believed), with the principle of security; Level 2 (Full Accredited), with the principle of integrated management; and level 3 (Accredited with Excellence), with the principle of excellence in management ${ }^{(1)}$.

The analysis of the cause, cited by interviewees, is a tool used to identify the basic or causal factors responsible for the variation in the performance, including the occurrence or almost occurrence of an adverse event, permanent injury or death ${ }^{(16)}$. However, it must be analyzed in an interdisciplinary way, that is, involving multiple managers, as the problem. Continually, deepens the five whys (5W technique: what to do, who, when, where and why) at each level of the cause. It is a method that identifies which changes have to be made in the system or processes to avoid variations ${ }^{(16)}$.
It is noteworthy that the cause analysis is a tool to identify prevention strategies for the safety of the patient and professional, making a review of systems and processes. The goal is to find out what happened, why it happened and what to do to prevent any recurrence. In this sense, organizing processes is describe them formally, with constant review, streamlining the work, reflecting also reducing costs and rework, as explained in other studies ${ }^{(2,4)}$.

Therefore, to the extent of hospital accreditation, a spirited training was needed on the principles of quality, and it can develop professional skills related to leadership, ownership of new knowledge and the scope of an organized assistance related to the development of teamwork skills and communication $^{(2)}$.

The importance of quality tools should be reinforced to assist in continuous improvement. However, its inclusion is justified only if managers allying the data and use the recorded information to evaluate and reorganize the management and health practices. It should be an approach to the management of the area, which is the organizational transformation, a composition in the organization through integrated action, or only able to happen when there is the action of its members, and this action can bring meanings attributed to work ${ }^{(17)}$. Knowing the characteristics of the work to give meaning to those who take it can guide decisions and activities of the responsible organizational transformation process ${ }^{(18)}$.

Work is essential in people'slives ${ }^{(18)}$, by inserting new instruments and changes in management actions can lead to new learning, which in turn, generates knowledge, tasks, autonomy, recognition and security, fundamental to make sense at work ${ }^{(18)}$.

However, it is emphasized that action to manage goes beyond implementation of rules and routines, organization, control, and education; it involves innovation and perseverance ${ }^{(19)}$. With innovation, there is involvement of common actions, generating 
fears about the possibility of control of new routines.

In this sense, changes must be gradually improved and, over time, incorporated into the work routine. Therefore, accreditation is a continuous process, with steps to achieve and should be a periodic process (with intervals of two or three years) (1) because the quality is a permanent construction and reconstruction process.

As the professional reacts to change and problematic situations, he transits a so-called continuous learning model, which is to recognize that knowledge, skills, and attitudes must be renewed to maintain an appropriate level of professional quality ${ }^{(20)}$. It is important to recognize the prospect of change as emerging learning, as a channel to seek new ideas, continuing education ${ }^{(20)}$, leaving the organization to encourage people in this search.

\section{Conclusion}

Thisstudyidentified changesin themanagement actions taken after hospital accreditation. There were more methods incorporated in the manager's work to continuous improvement. There was an organization of managerial work which resulted in the adoption of new administrative, basic tools for managerial function guided by the quality policy; added to the personal responsibilities that operate as it is through this responsibility they started to carry out their work. However, there were challenges to overcome.

Regarding the limitations of the study, it is pointed out that although held in a reference hospital in quality, accredited in Excellence, it cannot express the reality of other institutions. Thus, further studies should be performed for larger generalizations of the results.

\section{Collaborations}

Siman AG contributed to the project design, collection, organization, analysis and interpretation of data, article writing and final version to be published. Cunha SGS contributed to the construction of the article and assisted in the review. Brito MJM contributed to the project, organization, analysis, interpretation of data and helped in reviews.

\section{References}

1. Organização Nacional de Acreditação (ONA). Manual brasileiro de acreditação: organizações prestadoras de serviços de saúde. Brasília: ISQua ONA; 2014.

2. Siman AG, Brito MJM, Carrasco MEL. Participação do enfermeiro gerente no processo de acreditação hospitalar. Rev Gaúcha Enferm. 2014; 35(2):93-9.

3. Consórcio Brasileiro de Acreditação de Sistemas e Serviços de Saúde (CBA). Padrões de acreditação da Joint Comission International para hospitais. Rio de Janeiro: CBA; 2011.

4. Manzo BF, Ribeiro HCTC, Brito MJM, Alves M. Nursing in the hospital accreditation process: practice and implications in the work quotidian. Rev Latino-Am Enfermagem. 2012; 20(1):151-8.

5. Donabedian A. An introduction to quality assurance in health care. New York: Oxford University Press; 2003.

6. Kobayashi RM, Silva ABV, Ayoub AC. Gerenciando dificuldades para acreditação hospitalar em hospital cardiovascular. Rev Rene. 2010; 11(4):19-28.

7. Yin RK. Estudo de caso: planejamento e métodos. Porto Alegre: Bookman; 2010.

8. Polit DF, Beck CT. Fundamentos de pesquisa em enfermagem: avaliação de evidências para a prática da enfermagem. Porto Alegre: Artmed; 2011.

9. Bardin L. Análise de conteúdo. Lisboa: Edição 70; 2011.

10. Silva VLS, Camelo SHH. A competência da liderança em enfermagem: conceitos, atributos essenciais e o papel do enfermeiro líder. Rev Enferm UERJ. 2013; 21(4):533-9. 
11. Drucker P. The theory of business. Harvard Bus Rev. 1994; 75(1):95-105.

12. Quinto Neto A. Riscos assistenciais hospitalares: questão humana e econômica. Rev Adm Saúde. 2011; 13(50):31-8.

13. Joint Commission on Acreditation of Health care Organization. Characteristics of clinical indicators. Qual Rev Bul. 1989; 15(11):330-9.

14. Schiesari LMC. Avaliação externa de organizações hospitalares no Brasil: podemos fazer diferente? Ciênc Saúde Coletiva. 2013; 19(10):4229-34.

15. Feldman LB. 0 gestor da área de gerenciamento de riscos. In: Alves VLS, Feldman LB, organizadores. Gestores da saúde no âmbito da qualidade: atuação e competências abordagem multidisciplinar. São Paulo: Martinari; 2011. p. 209-29.

16. Novaes HM. O processo de acreditação dos serviços de saúde. Rev Adm Saúde. 2007; 9(37):133-40.

17. Andrade SPC, Tolfo SR, Dellagnelo EHL. Sentidos do trabalho e racionalidades instrumental e substantiva: interfaces entre a Administração e a Psicologia. Rev Adm Contemp. 2012; 16(2):20016.

18. Morin E, Tonelli MJ, Pliopas ALV. O trabalho e seus sentidos. Psicol Soc. 2007; 19:47-56. 
19. Fernandes HS, Silva E, Capone Neto A, Pimenta LA, Knobel E. Gestão em terapia intensiva: conceitos e inovações. Rev Bras Clin Med. 2011; 9(2):129-37.

20. Castillejo JAP. Las sociedades científicas y la gestión del conocimiento, un paso más allá del desarrollo profesional continuo. Atenç Prim. 2010; 42(6):338-1. 